\title{
The verdict's in: citizens are the solution
}

$\mathrm{T}$ hey've become a virtual staple of the health reporter's repertoire: heart-wrenching stories about innocent people on death watch because they simply can't afford the exorbitant cost of the pharmaceutical solution to their ailments.

The bad guys, of course, are politicians and the faceless bureaucrats who run public drug plans and are cast as miserly and ruthless, rather than as harried officials forced to make tough, sometimes controversial, funding decisions as they grapple with limited budgets, soaring drug costs (particularly, stiff hikes in cancer drug prices), and new drugs about which little is known, but much is promised.

Well, the "bad guys" are finally getting some help. Across Canada, members of the public are being asked to help tackle what Helen Stevenson, executive director of Ontario's $\$ 3.5$ billion public drug plan, describes as "the big, big drug-related policy issues."

In May, Ontario launched an ambitious version of the citizen solution when it began advertising to recruit for a 25 member Citizens' Council which will, on an ongoing basis, provide advice to Stevenson. The move is part of a larger trend in developed countries to involve more members of the public and patient groups in the health care system. Indeed, Ontario's new council is modelled after a 2004 United Kingdom initiative that attracted almost 40000 citizen applicants (see sidebar). It, however, tackles a broader range of public health care issues, not just drug policy. It reports to the National Institute for Health and Clinical Excellence, an arm's length body that advises the National Health Service.

Ontario's council will be more limited but will still tackle "big questions," such as whether society should fund, in a climate of scarce resources, drugs for rare diseases, where there is little evidence of efficacy, high costs and few beneficiaries, Stevenson says. The council, which will meet twice a year, will not be expected to reach consensus; instead, its opinions will be reported. It's not yet clear whether the council will consider decisions around cancer drugs, the costs of which have increased on average about $30 \%$ annually.

Public representatives have been playing a role in other provinces, most often in multi- stakeholder committees like one in Nova Scotia that advises on cancer drug coverage. Caregivers have been asked to provide advice as part of a study of dementia drugs in British Columbia, while the national Common Drug Review has 2 public members on its Cana- dian Expert Drug Advisory Committee, which reviews and analyzes clinical and economic evidence for new drugs and makes funding recommendations to public drug plans in Canada (except Quebec).

Similar bodies have been convened in Canada to look at specific issues, such as the Citizens Assembly on Electoral Reform in British Columbia or a Public Health Agency of Canadafunded public advisory group on the use of xenotransplantation in clinical trials (CMAJ 2002;167[1]:40-2).

The latter revealed that citizens (who in that instance called for a xenotransplantation moratorium) tend to look at an issue more broadly, says Edna Einsiedel, a communications studies professor at the University of Calgary who worked on the consultation. When citizens come to an issue they can "shift the context of the debate, look at the way the debate is structured and the problem is framed," says Eisiendel, whose area of interest is public representation and participation on science and technology issues.

The new Ontario body will be the first ongoing all-citizen council advising a provincial drug plan. The idea is to "explicitly segregate challenging social questions" from the other factors drug plan managers must tackle, says

\section{Britain's experience: gardeners and}

\section{students made a difference}

From movies or television, most of us are familiar with how US grand juries operate - members fire tough questions at a group of witnesses seated at the front of the room.

That's pretty much how a Citizens' Council functions, says Paddy Storrie, a high school administrator in England who just finished a 3-year term on a council that advises the United Kingdom's National Institute for Clinical Excellence.

"I was really struck by the high profile of the people that presented to us - top people in the National Health Service and government," says Storrie, 1 of the almost 40000 applicants who vied for 30 original spots on the council. "We were just people dragged off the street, but still we were confronted with the top experts. It gave us a real sense of importance."

Council members included a gardener, air hostess, stu- dents and unemployed people - "a bit of the UK demographic, and plenty of cynics about government."

Storrie stressed that the council was "not just a rubber stamp" and its take on issues sometimes surprised bureaucrats, as when the council concluded that age should not be a factor in the allocation of health care resources.

In addition to hearing from a range of experts and witnesses, the council, which was set up to provide an "ethical steer" on tough public policy questions, examined case studies and engaged in "facilitated debate" over each 3-day meeting.

Storrie was sad to have to step down: "it was just brilliant, really stretching. And I was really impressed with my colleagues; we sometimes had to consider some quite technical information and explain things to each other."

In 2005, an independent evaluation of the council found that the process was valuable but "not a cheap option ... [and one] that delivers something different from, for example, a public opinion survey, an advisory group or a stakeholder dialogue." 

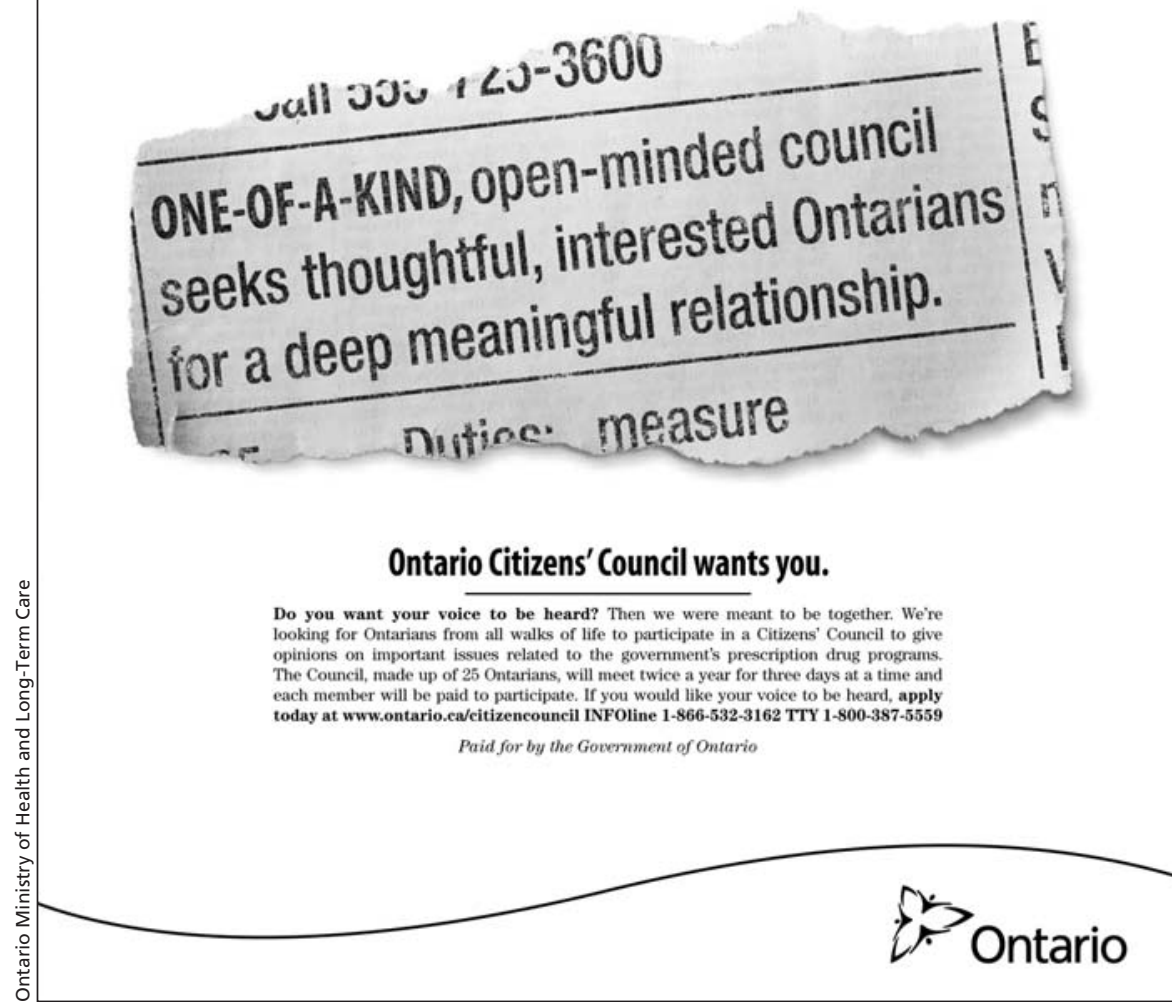

Ontario recently began advertising for recruits to a 25-member Citizens' Council that will provide advice to the province's public drug plan on which pharmaceuticals to include in its coverage.

President and CEO of Cancer Care Ontario Terrence Sullivan.

"There is an increasing recognition that we as professionals can't be proxy for social questions," explains Sullivan, who is conducting research in the area of public participation. "The Citizens' Council is a very explicit democratic input, from a citizen, not a patient, point of view."

The Citizens' Council could be a "very good thing," provided the members have no ties to commercial sectors that could profit from decisions and that the council not simply serve as windowdressing, says Anne Rochon Ford, coordinator for Women and Health Protection, a coalition concerned about the safety of pharmaceutical drugs. "Organizers should be aware that many citizens are getting very disillusioned with their engagement with government bodies, having seen too often that their time was wasted on committees where their input was ultimately not at all evident in final decisions."

The council is one of 2 consultative bodies promised in the province's 2006 Transparent Drug System for Patients Act. While the Ontario Pharmacy Council was up and running by December 2006, the start date for the Citizens' Council is November 2008. "It took some time to develop a recruitment process to reach out to all Ontario," says Stevenson, explaining the need to balance privacy rules with that of attracting candidates from a representative range of ethnic groups (by way of 55000 recruitment brochures being distributed to community agencies, and a $\$ 176500$ print media campaign). Candidates will be screened by an arm's length agency.

Stevenson surmises that it will be helpful that most council members will not be beneficiaries of the province's drug plan, which primarily provides drugs for senior citizens and social assistance recipients. "They will be neutral," unlike the UK council, whose members all benefit from the National Health Service.

The concept of citizen involvement in aspects of health care delivery is rel- atively new, and many credit AIDS activists with pushing the envelope. Twenty-five years ago, when Ontario was establishing a task force on AIDS and activists sought a place at the table, then-Ontario health minister Larry Grossman is reported to have dismissed the bid with the remark: "We have an advisory committee on cancer and we don't have cancer victims on it." Ann Silversides, CMAJ

DOI:10.1503/cmaj.080876

\section{Congo ceasefire brings}

\section{little relief for women}

S exual terrorism. It's the only way to describe what is happening to women in the Democratic Republic of Congo, according to doctors at Panzi Hospital in the eastern province of South Kivu.

"If you combine HIV and sexual violence in Eastern Congo, this is a condition that is sufficient to affect the whole of humanity, to destroy a whole society, to destroy a whole people, slowly but surely," says Panzi surgeon Dr. Roger Luhiriri.

Although the shooting war supposedly ended with a peace agreement in January 2008, "the war on women continues," says Stephen Lewis, former United Nations special envoy for HIV/AIDS in Africa. That's why his foundation donated another $\$ 300000$ in June 2008 to the Panzi Hospital.

"The wanton ferocity of the sexual violence allows for the frequent transmission of the virus," Lewis adds. It finds an easy passage through women's torn bodies, which are often subject to what Lewis calls "vaginal destruction." Their entire reproductive systems are shredded by attacks with guns, branches or batons, he says. Often, the women are raped in front of their families.

The hospital gives free treatment to about 3500 survivors of sexual violence each year, a third of them children, $10 \%$ of them HIV-positive. A 2006 UN study found 50000 reported cases of rape since the beginning of the conflict, but it acknowledged that number as only a 